\title{
Intestinal knot in acute Meckel's diverticulitis
}

\author{
Don Evana Ezrien, ${ }^{1}$ Firdaus Hayati (D) , ${ }^{2}$ Nik Amin Sahid Nik Lah, ${ }^{2}$ \\ Andee Dzulkarnaen Zakaria (D) ${ }^{3}$
}

${ }^{1}$ Department of Surgery, Queen Elizabeth Hospital, Ministry of Health Malaysia, Kota Kinabalu, Sabah, Malaysia

${ }^{2}$ Department of Surgery, Faculty of Medicine and Health Sciences, Universiti Malaysia Sabah, Kota Kinabalu, Sabah, Malaysia

${ }^{3}$ Department of Surgery, School of Medical Sciences, Universiti Sains Malaysia, Kubang Kerian, Kelantan, Malaysia

\section{Correspondence to Dr Firdaus Hayati; \\ firdaushayati@gmail.com}

Accepted 15 October 2019

\section{DESCRIPTION}

A 47-year-old man, with no past surgical history presented to the emergency department with colicky abdominal pain since 2 days prior to the admission. It was associated with abdominal distension, vomiting and no bowel output. The pain became worsened which resulted in his immediate hospital visit. On examination, the abdomen was peritonitic. The blood investigations showed marked leucocytosis. There were signs of small blood obstruction on abdominal radiograph but no free gas on erect chest radiograph. He was immediately rushed to the emergency operation theatre and exploratory laparotomy was performed. Upon entry, there was gangrenous small bowel caused by an ileo-ileal knot with Meckel's diverticulitis, which was adjacent to the caecum (figures 1 and 2). We had to proceed with limited right hemicolectomy and functional end-to-end anastomosis using linear stapler. The recovery process was uneventful. Patient was discharged home after a week. On follow-up at 3 months, he was well with no complications. The histopathological examination was consistent with ischaemic bowel.

Acute abdomen is the most common surgical emergency leading to a high visit rate to the emergency department. It includes gastrointestinal perforation, ischaemia, inflammation and obstruction. Small bowel obstruction is a typical surgical condition requiring urgent intervention. Among the most usual aetiologies of strangulated intestinal obstruction include abdominal wall hernia, adhesion, congenital band, intussusception and volvulus. ${ }^{1}$ Volvulus or intestinal knot can lead to a closed loop phenomenon, strangulation, ischaemia and subsequent perforation. There are several types of intestinal knot namely appendico-ileal, ileo-caecal, ceco-sigmoid, ileo-sigmoid and ileoileal. $^{23}$ Among them, the ileo-ileal knot is a very rare entity. ${ }^{2}$ Intestinal knot was first described as

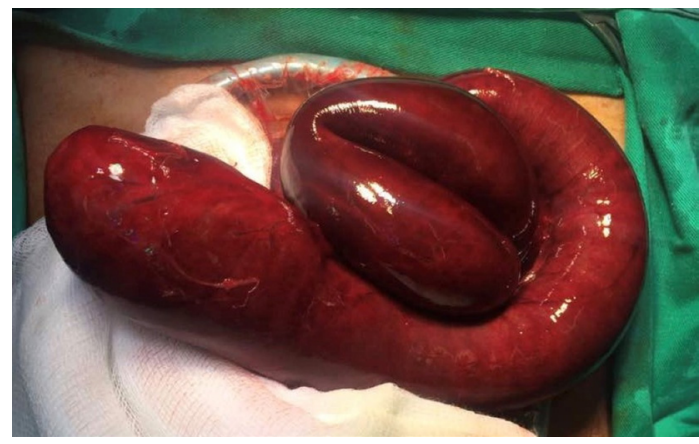

Figure 1 A gangrenous loop of small bowel with Meckel's diverticulitis.

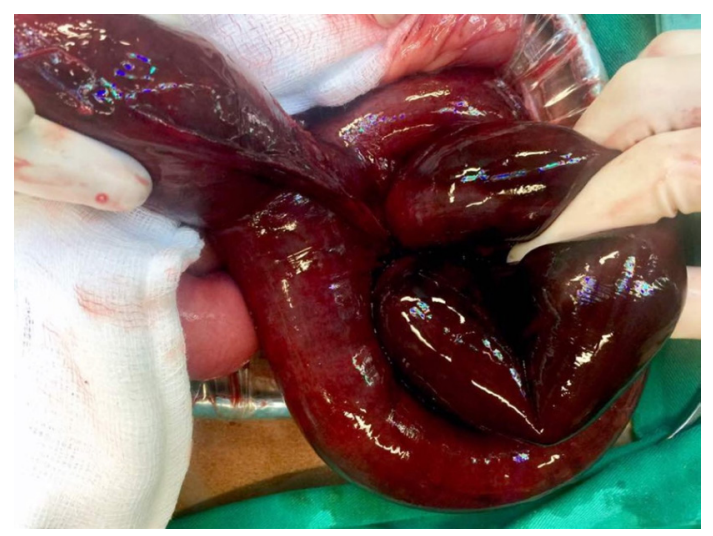

Figure 2 Internal herniation through the intestinal knot.

early as in the 16th century and later in the 18th century. ${ }^{4}$ Typically, patients will present with acute abdomen either due to strangulation, obstruction and even as late as septic shock secondary to bowel perforation. It is postulated that the causative factors for intestinal knot are anatomical variation and dietary habit. ${ }^{35}$ Our patient had another incidental finding of Meckel's diverticulum in which the possibility of Meckel's diverticulitis and mesodiverticular obstruction causing acute abdomen needed to be considered. ${ }^{67} \mathrm{CT}$ scan is required for a preoperative diagnosis but not in a case of peritonitis which requires immediate surgical intervention. During surgery, it is advisable to untie the knot

\section{Patient's perspective}

I am happy with the result after the operation. The pain in my abdomen has resolved. I am honoured that my case can be contributed medically to the society.

\section{Learning points}

Intestinal knot should be considered as a differential diagnosis of an acute abdomen.

- Acute abdomen in Meckel's diverticulum can either be diverticulitis, mesodiverticular obstruction or perforation.

- A viable bowel segments are advisable to untie the knot but bowel resection is for a gangrenous intestine.

- A controlled decompression before untying a gangrenous knot is recommended to avoid reperfusion injury. 
if the bowel segments are viable. For a gangrenous intestine, bowel resection is warranted. If irreversible ischaemic segment is found, controlled decompression by enterotomy before untying a gangrenous knot is recommended besides to be cautious on reperfusion injury. ${ }^{4}$ Short bowel syndrome should be considered after surgery depending on the length of the remaining small bowel.

Acknowledgements We would like to thank the Director General of Health Malaysia for his permission to publish this article as case report.

Contributors DEE: wrote the course of the disease. FH: searched for literature review. NASNL: edited manuscript. ADZ: revised manuscript.

Funding The authors have not declared a specific grant for this research from any funding agency in the public, commercial or not-for-profit sectors.

Competing interests None declared.

Patient consent for publication Obtained.

Provenance and peer review Not commissioned; externally peer reviewed.

\section{ORCID iDs}

Firdaus Hayati http://orcid.org/0000-0002-3757-9744

Andee Dzulkarnaen Zakaria http://orcid.org/0000-0002-4826-9725

\section{REFERENCES}

1 Yang K-H, Lee T-B, Lee S-H, et al. Congenital adhesion band causing small bowel obstruction: What's the difference in various age groups, pediatric and adult patients? BMC Surg 2016;16.

2 Abebe E, Asmare B, Addise A. lleo-ileal knotting as an uncommon cause of acute intestinal obstruction. J Surg Case Rep 2015;2015. doi:10.1093/jscr/rjv102

3 Gopivallabh MM, Jaganmaya K, Hanumanthaiah KS, et al. lleoileal knot as a content of obstructed hernia: what are the odds? Iran J Med Sci 2016;41:238-40.

4 Taniguchi K, lida R, Watanabe T, et al. Ileo-ileal knot: a rare case of acute strangulated intestinal obstruction. Nagoya J Med Sci 2017;79:109-13.

5 Uday SK, Venkata PKC, Bhargav PRK, et al. Ileo-ileal knot causing small bowel gangrene: an unusual presentation. International Journal of Case Reports and Images 2012:3:28-30.

6 Affirul CA, Firdaus $\mathrm{H}$, Hanizah N, et al. Meckel's diverticulitis in adulthood: a revisit. Surg Chron 2018;23:239-41.

7 Teng WW, Yeap BT, Azizan N, et al. Gangrenous giant Meckel's diverticulitis masquerading acute appendicitis: a surgical conundrum. ANZ I Surg 2019:89:E379-80

Copyright 2019 BMJ Publishing Group. All rights reserved. For permission to reuse any of this content visit

https://www.bmj.com/company/products-services/rights-and-licensing/permissions/

BMJ Case Report Fellows may re-use this article for personal use and teaching without any further permission.

Become a Fellow of BMJ Case Reports today and you can:

- Submit as many cases as you like

- Enjoy fast sympathetic peer review and rapid publication of accepted articles

- Access all the published articles

Re-use any of the published material for personal use and teaching without further permission

Customer Service

If you have any further queries about your subscription, please contact our customer services team on +44 (0) 2071111105 or via email at support@bmj.com.

Visit casereports.bmj.com for more articles like this and to become a Fellow 